\title{
Landasan Ilmiah Ilmu Informasi Perpustakaan dalam Perspektif Ilmu Komunikasi
}

\author{
Rohanda \\ Departemen Ilmu Informasi dan Perpustakaan Fikom Unpad \\ Jl. Raya Bandung-Sumedang Km. 21 Jatinangor 45363 \\ Email:r_rohanda@yahoo.com
}

\begin{abstract}
Abstrak - Inti persoalan yang dibahas dalam artikel ini adalah konsep, landasan filosofis dan landasan ilmiah Ilmu Informasi dan Perpustakaan dalam berbagai perspektif. Mengingat Ilmu Informasi dan Perpustakaan begitu luas, komprehensif dan interdisiplin sehingga membingungkan dalam penempatan atau pemberian alamat dan wadahnya di bidang rumpun ilmu tertentu. Apakah masuk rumpun Ilmu Budaya, Sosial, Komunikasi, Teknologi atau pada kelompok Sains dan Matematika. Kemudian, apakah berdiri sendiri atau sebagai ilmu interdisiplin. Belum ada jawaban yang pasti. Ilmu Informasi dan Perpustakaan diformulasikan sebagai konsep interdisiplin mengingat ilmu tersebut dalam pembagian klasifikasi DDC, masuk pada kelompok General Science (ilmu pengetahuan umum), artinya ilmu tersebut dapat berdiri sebagai disiplin ilmu sendiri, tidak bergabung dengan ilmu lain sebagai sub divisi dari bidang lain, sehingga dengan tulisan ini dirancang dan diperkenalkan landasan ilmiah yang sekaligus memberitahukan alamat yang jelas tentang kedudukan ilmu tersebut. Paradigma baru Ilmu Informasi dan Perpustakaan merupakan ilmu yang stabil layaknya ilmu modern yang tidak lagi memandang dunia kerja saja, akan tetapi lebih ke arah pengembangan strategi pemecahan masalah yang begitu luas dan rumit. Sebagai satu kesatuan ilmu, Ilmu Informasi dan Perpustakaan sudah seharusnya mandiri, tidak menempel atau ditempelkan pada bidang ilmu lain.
\end{abstract}

Kata Kunci: Landasan ilmiah, Ilmu Informasi dan Perpustakaan, perspektif Ilmu Komunikasi

Abstract - The main issue explained in this article is about concept, philosophical foundation, and scientific basis of Information and Library Science in various perspectives. Considering that Information and Library Science is so widely, komprehensive, and interdisciplinary so that confusing in placement or the provision of objective and receptacle in particular cluster field of science. Is it included in Cultural Science cluster, Social, Communication, Technology, or in Science Group and Mathematical Science. Then, is it stand alone or as an interdiscipline science. There's no answer yet. Information and Library Science formulated as interdicipline concept considered that the science is in General Science in DDC classification division, which is means that the science can stand as a discipline itself, unmerged with another science as a subdivision from other field, so with this article designed and introduced the scientific basis and also the definite objective about the position of the science. New paradigm of Information and Library Science as a stabil science like other modern science which no more just see the world of work, but more that that. Information and Library Science also see the development of problemsolving strategies that are so extensive and complicated. As a unity of science, Information and Library Science should be independent, not adhere or affixed tp other science field.

Keywords: Scientific basis, Information and Library Science, Communication Studies perspective

\section{PENDAHULUAN}

Daniel N. Jondrey, Guru Besar pada School of Library and Information Science Simmons Colledge, kemudian Arlene G. Taylor (2009) menyatakan bahwa informasi dapat dipandang sebagai komoditas (barang) atau benda yang dapat diperjualbelikan dan ditukar. Hal ini senada dengan pendapat dari Audrey Fenner bahwa informasi merupakan aset (kekayaan) dalam bentuk data yang telah diolah atau dikemas dalam berbagai media, seperti apa yang disebut sumber informasi (information resources).

Fenner mengatakan, "Business regards information as a commodity and the possession of it as an asset. Economists would like to treat and account for information in the same way as physical assets." (Fenner, 2005) Diungkapkan oleh Shannon dalam bentuk matematik seperti $\mathrm{H}=$ $\Sigma \mathrm{P}(\mathrm{x})-\log \mathrm{P}(\mathrm{x})=\quad \Sigma-\mathrm{P}(\mathrm{x}) \quad \log \mathrm{P}(\mathrm{x}) \quad$ dikumpulkan dalam bentuk data atau narasi dan angka. Angka juga data dan susunan huruf-huruf yang mempunyai nilai dan makna bagi responden. Rumus ini untuk menghitung berapa jumlah karakter dalam sebuah pesan atau dinyatakan dalam BIT (Binnary Digit) $1 / 2 X \log (1 / 2)+1 / 2 X$ $\log .(1 / 2)=1$ bit (Shannon \& Weaver, 1945)

Komentar Werner Gitt bahwa teori informasi yang berkembang pada 20-30 tahun terakhir dan 
diterima sebagai bagian dari termodinamika menyatakan bahwa informasi adalah sesuatu yang berbeda dari materi, tidak pernah dapat direduksi menjadi materi. Asal usul informasi dan materi fisik harus diselidiki secara terpisah (Yahya, 2005).

Sumber informasi di dalam setiap buku adalah pikiran dari penulis yang menulis buku itu. Sebab buku awalnya terbentuk dari alam pikiran penulis yang menulis buku itu (Yahya dan Harun, 2005). Penulis membangun rangkaian logika di dalam pikirannya kemudian mengurutkannya dalam bentuk kalimat-kalimat dan mewujudkannya ke dalam bentuk materi (buku). Dengan demikian bahwa informasi tidak dapat direduksi menjadi materi karena ia datang dari sumber materi.

Pandangan Michael Buckland (1998) Pada School of Information Management and System mensitir pendapat Founded (1973) yaitu: information as a cognitive process, information as knowledge imported and signifying object (data, document, and the like). Information is commonly used metaphorically or so abstractly that the meaning is unclear. (Buckland, 1998). Sebelumnya Prancis Bacon di tahun 1597 menyatakan "Information is power", karena mengambil pernyataan dari knowledge is power, karena Information is knowledge. (human knowledge and human power meet in one).

Berbeda dengan pandangan Fenner yang menyatakan bahwa informasi merupakan elemen dari komersial, dan merupakan komoditas (barang) yang dapat dijualbelikan (Economic Theories of Information). (Fenner, 2002). Teori ini menyatakan bahwa informasi merupakan sesuatu benda yang dapat diukur dan mempunyai nilai yang dihitung berdasarkan suplay dan demand (persediaan dan permintaan). Nilai Ekonomis dimaksud tidak didasarkan atas wujud fisiknya melainkan lebih kepada kegunaan atau keterpakaiannya.

Dengan demikian dapat diungkapkan bahwa :

- Informasi adalah data yang diolah dan dikemas dalam berbagai bentuk media yang disebut sumber informasi. (information resources)
- Informasi adalah kata (narasi), angka dan data yang tersusun dan mempunyai nilai atau makna.

- Informasi dirumuskan sebagai bentuk $\mathrm{H}=$ $\Sigma \mathrm{P}(\mathrm{x})-\log \mathrm{P}(\mathrm{x}) \quad$ yang hasilnya merupakan bit (Binnary Digit).

$\mathrm{P}=$ Probabilitas dari nilai $\mathrm{X}$

$\mathrm{X}=$ Merupakan kode dari pesan

Log $=$ Daftar Logaritma

- Informasi merupakan rangkaian dari nilai angka 0 dan 1 (Binnary)

- Informasi sesuatu komoditas yang sulit diukur nilainya.

- Pustakawan memandang dirinya sebagai "Profesional Informasi" karena ia yang mengkomunikasikan atau melakukan proses penyebaran informasi kepada khalayak melalui media komunikasi (cetak dan non cetak/ elektronik).

- Media komunikasi cetak seperti buku, jurnal, majalah, surat kabar, dan bentuk lembaran disebut sumber informasi. Termasuk juga media elektronik TV, radio, dan internet disebut juga sumber informasi elektronik.

- Nilai ekonomi informasi dapat dilihat dari harga sumbernya karena informasi merupakan komoditas yang tidak berbentuk fisik.

\section{PETA KEILMUAN ILMU INFORMASI}

Konsep masyarakat informasi (Information Society) Amerika sejak tahun 1937, bahwa Ilmu Informasi mengkonsentrasi pada dua tradisi. Peta keilmuan (landcafe) Ilmu informasi ialah tradisi "dokumentasi" dan tradiri komputerasional. Tradisi dokumentasi yaitu teknik pengelolaan informasi secara manual. Sedangkan tradisi komputerasional yaitu aplikasi dan algoritmik, logika dan teknik mekanik dalam pengelolaannya. Akar dari Ilmu Informasi adalah berada pada dua sisi. Bagi tradisi dokumentasi, berada pada paradigma ilmu sosial dengan pendekatan 
Kualitatif Sosial Sain. Sedangkan pengelolaan informasi dengan implementasi paradigma matematik, algoritmik, logika dan teknik mekanik masuk pada paradigma Kuantitatif Sain. Dengan demikian ilmu informasi berada pada dua sisis ilmu sosial dan ilmu pengetahuan alam (Sain).

\subsection{Tradisi Dokumentasi}

American Society For Information Science menyatakan bahwa yang dimaksud dengan tradisi dokumentasi adalah pengelolaan dokumen (record) arsip, buku, majalah, jurnal, CD, Foto dan media lainnya, mulai dari pengumpulan (collecting), pemilihan (selecting), pelestarian (preserving) pengorganisasian (organizing) atau penyusunan, penyajian, penelusuran kembali (retrieving), reproduksi (fotocopy), interpretasi (penerjemahan), meringkas dan penyebaran dokumen. Dengan kata lain tradisi dokumentasi merupakan kegiatan bibliografis atau kepustakawanan. Dokumentasi merupakan kata lain dari ilmu informasi.

\subsubsection{Logika tradisi dokumentasi.}

Profesi khusus bidang informasi mengkonsentrasikan diri pada manajemen dokumen. Hal ini mencakup keahlian adalah pengelolaan arsip, bibliografi, perpustakaan, manajemen record (pengelolaan cantuman), pengindeksan, penelusuran informasi, dan kegiatan seperti itu. Tradisi dokumentasi pada dasarnya adalah pengelolaan pengetahuan untuk berbagai kepentingan, pendididkan, rekreasi literasi, komunikasi, persuasi, dan untuk mensupport pembuatan keputusan dan seterusnya.

Logika tradisi dokumen meliputi:

1. Manajemen dokumen mencakup analisis berbagai jenis dokumen seperti manuskrip, grafik, dokumen 3D, model, dan berbagai dokumen digital atau fokus kepada database digital.

2. Manajemen informasi di dalamnya mencakup pesan, pengetahuan, pemaknaan, pembelajaran, bahasa, dan memfokuskan pada aktifitas sosial budaya. Pada konteks ini, tradisi dokumentasi masuk pada paradigm ilmu sosial-budaya karena tidak hanya mengkaji implementasi pada aspek teknologi, tapi juga mengkaji tentang masalah kemanusiaan (human being) yaitu pengguna (user) baik secara individu, kelompok, masyarakat, atau komunitas tertentu misalnya para sarjana, atau para ilmuan.

Jadi pada tradisi dokumentasi ini masuk kepada akar ilmu budaya, humanistis dan sosial yang kualitatif.

\subsubsection{Logika Tradisi Komputasional}

Tradisi ini muncul disebabkan oleh keberhasilan algoritmik, logika, mekanik, dan fasilitas matematik dalam problematika pengeloaan dokumen. Sebagai contoh Punch Card (peak-a-boo) dan pola rekognisi teknik, proses data, dan komputer digital, seperti; sistem informasi manajemen, artificial intellegence dan penelusuran informasi (retrievel of information). Komplementar tapi bukan konvergen (pandangan pada satu titik, pandangan tentang akar informasi). Dua tradisi ilmu informasi yaitu dokumentasi dan komputasi yang mempunyai fondasi berbeda dimana dokumentasi mengakar ke ilmu sosial, budaya dan humaniora. Sedangkan komputasi mengakar pada bidang sains dan teknologi. Sebagai contoh MIS (Management Information System) dengan menggunakan cantuman alphanumeric dan layanan perpustakaan pun menggunkan sistem yang sama seperti cantuman tanggal, nama, dan nomor identitas. Namun untuk MIS, operasionalisasinya (domain speciphic) bagi kepentingan pengambilan keputusan maka data tersebut diolah secara komputer yaitu untuk percepatan akses. Adapun layanan perpustakaan walaupun yang diolahnya sama (alphanumeric) tapi tipe datanya (dokumen, teks , gambar, video) tidak selamanya diolah secara komputer, karena penggunaannya dalam lingkup cepat memerlukan akses yang lebih cepat, domain spesifik, dan lebih tepat untuk operasional, pembuatan keputusan (decision making) yang bersifat taktis, yaitu cepat, tepat dan akurat.

Sedangkan tradisi dokumen (sebagai contoh: jasa perpustakaan) tipe pencariannya non-meric dokumen sehingga akan lebih relevan untuk pembuatan keputusan yang bersifat strategis. Dikotomi pembagian dua paradigma yaitu, paradigma numeric dan non-numeric dalam pengelolaan dokumen sebagai sumber informasi, kaitannya dengan pembuatan keputusan, dimana tradisi dokumentasi adalah untuk keputusan strategis, sedangkan tradisi komputerisasi untuk 
keputusan taktis. Walaupun kedua-duanya dapat difungsikan sama. Maka pandangan terhadap pemisahan seperti itu (konvergen) bukan merupakan suatu pemisahan yang jelas namun, sebatas pengkondisian saja kaitannya dengan operasional sistem informasi manajamen (SIM) yang mengelompokan keputusan manajerial pada tataran taktis dan strategis.

Paradigma konvergen (Filsafat Immanuel Kant) memandang bahwa ilmu merupakan satu kesatuan yang intinya memisahkan antara tradisi dokumentasi dan komputasi, yang memandang terhadap keahlian pustakawan dimana mayoritas rendah minatnya terhadap komputer, dianggap interesnya pustakawan perempuan. Sementara laki-laki interesnya tinggi, sehingga penyusunan program pendidikan yang berbeda antara kurikulum untuk laki-laki dan perempuan. Pandangan konvergensi didasari pada kondisi tersebut. Sedangkan paradigma komplemen tidak mendikotomikan dua pendapat tadi. Dua paradigma itu merupakan satu kesatuan. Hal ini pun akan berdampak pada waktu penyusunan kurikulum program pendidikan perpustakaaan.

\section{ILMU INFORMASI: ASAL, EVOLUSI DAN RELASI}

Tefko Sarasvic berpendapat bahwa tujuan tulisan ini mengeksploitasi evolusi dan perubahan ilmu informasi. Poper (1972) berargumen bahwa kami bukan mahasiswa untuk beberapa subject metter (disiplin ilmu) tapi mahasiswa untuk mengkaji beberapa masalah. Dari permasalahan tersebut mahasiswa akan memahami subject metter (disiplin ilmu). Bidang ilmu informasi dapat didefenisikan sebagai suatu permasalahan untuk dipecahkan melalui pendekatan keilmuan dan profesi praktis, hal ini akan mempengaruhi pemilihan metode pendekatannya, sehingga bidang ini tidak hanya didefenisikan secara bahasa (lexical) atau hanya ontologi saja.

Ilmu informasi secara umum ada yang tetap dan ada yang berubah (evolution and existence). Beberapa karakteristik ilmu modern adalah: Pertama, adalah interdisiplin, artinya adanya hubungan dengan bidang ilmu lainnya. Kedua, ilmu informasi adalah hubungan tawar-menawar (inexorably), dengan teknologi informasi. Dikarenakan perkembangan masyarakat modern (modern society) adalah masyarakat informasi (information society), atau disebut dengan abad "informasi" atau "post industrial society", semuanya ditandai dengan perkembanagan implementasi teknologi informasi (komputer). Ketiga, ilmu informasi secara aktif dan secara disengaja partisipasi pada evolusi ilmu informasi adalah munculnya masyarakat informasi karena kekuatan pengaruhnya adalah pada kekuatan perlakuan sosial dan dimensi manusia mengarah pada teknologi. Dengan demikian karakteristik atau kerangka kerja (frame work) pemahaman ilmu informasi baik saat ini atau kedepan adalah menangani isu-isu dan permasalahan dibidang itu.

\subsection{Asal Mula dan Latar Belakang Sosial}

Perkembangan ilmu pengetahuan dan teknologi setelah perang dunia kedua timbulnya inter koneksi atau inter disiplin bidang disiplin ilmu termasuk juga Ilmu Informasi. Mengkaji latar belakang sejarah perkembangan Ilmu Informasi sejak tahun 1945. Dalam artikel yang ditulis oleh Vannevar Bush (1945) ada dua pemikiran yang ia tulis yaitu:

- Dengan ringkas mendefinisikan permasalahannya sebagai bentuk terhadap beberapa pemikiran atas Ilmu Informasi beberapa waktu yang lalu

- Mengusulkan solusi "Technological Fix" (kesiapan teknologi) artinya dalam rangka memainkan spirit waktu dan strategi yang atraktif, dalam menangani penyimpanan pengetahuan (store of knowledge). Bush memberikan pangkal permasalahan (core of the problem) yaitu "ledakan informasi", tumbuh kembangnya informasi termasuk informasi terekam sehingga untuk penanganannya diperlukan kesiapan teknologi.

Para ilmuwan dan insinyur tahun 1950-an dan 1960-an menyusun program strategik untuk menangani ledakan informasi dalam berbagai bidang ilmu dan teknologi. Termasuk mengembangkan konsep-konsep Industri Informasi Modern. Pemikiran strategis yang dibuat untuk mendukung program-program dan usaha sebagai berikut:

- Sejak ilmu pengetahuan dan teknologi menjadi kritik utama bagi masyarakat (seperti di bidang ekonomi, kesehatan, komersil, pertahanan) sekaligus kritik ini ditujukan pada penyajian informasi relevan bagi individu, grup, dan 
organisasi dengan menggunakan pendekatan ilmu pengetahuan dan teknologi, maka informasi merupakan sesuatu yang penting sebagai bagian dari area pengetahuan dan teknologi itu.

- Pada tahun (1975) Wersig dan Nevelling memandang Ilmu Informasi secara historis dikembangkan sebagai jawaban terhadap problematik perubahan ilmu tersebut relevansinya pada masyarakat, dengan perkataan lain bahwa Ilmu Informasi merupakan pengetahuan yang dibutuhkan sebagai tanggungjawab sosial dan sekaligus sebagai latar belakang dari perubahan sosial, perubahan tersebut tidak hanya pada bidang ilmu informasi itu sendiri namun untuk keseluruhan pengetahuan, terutama kaitannya dengan Ilmu Komputer.

Perbincangan Ilmu Informasi semakin meluas baik secara teknis, konsep, dan sistem. Memandang bahwa ilmu tersebut dapat didefenisikan sebagai ilmu masyarakat yang kehadirannya untuk memecahkan permasalahan yang disebut sebagai ledakan informasi. Solusinya adalah adanya disiplin ilmu yang mempunyai konsep tentang:

- Bagaimana menjelaskan intelektualitas informasi.

- Bagaimana mengkaji intelektualitas tersebut.

- Sistem, teknik, atau mesin apa yang dapat mengolah, menyimpan intelektual tersebut.

Dikaitkan dengan filsafat ilmu, yaitu ontologi, epistemologi, dan aksiologi. Maka hakekat Ilmu Informasi itu mengandung arti tentang intelektualitas. Apakah informasi itu sebagai pesan, berita, pengetahuan, atau data yang telah diolah untuk suatu keperluan.

Berikutnya adalah bagaimana penelusuran intelektualitas tersebut. Dalam filsafat ilmu dapat diartikan sebagai epistemologi yaitu suatu cara (metode) bagaimana intelektualitas itu dibangun, dikemas, disimpan, dan ditelusur untuk berbagai kebutuhan, dalam ilmu perpustakaan dikenal istilah informasi teori Know-How, bagaimana memperoleh dan bagaimana menggunakan informasi dalam pemenuhan kebutuhan individu secara tepat, tentunya diperlukan kemampuan dan tentang bagaimana penelusuran informasi itu.

\subsection{Teori Ilmu Informasi}

Analisis, investigasi, deskripsi dari teori (Webster International Dictionary 1969)

\section{Teori}

a. Batang tubuh dari generalisasi dan prinsipprinsip yang dikembangkan pada asosiasi dengan praktis pada pembentukan lapangan aktivitas dari disiplin intelektual.

b. Sistem dari berbasis asumsi, prinsip-prinsip dan aturan untuk menganalisis, memprediksi atau menyelesaikan secara alami dari suatu kesatuan fenomena.

c. Model adalah suatu tentatif dari ide yang digunakan, alat coba (American Heritage 1969)

\section{Epistemologi}

Apakah pengetahuan sebaiknya dipahami secara keseluruhan

- Empirisme melekat apa adanya.

- Residualisme pengetahuan dibangun dari hasil pemikiran manusia.

- Konstruktivisme. Pengetahuan dibangun berdasarkan persepsi manusia terhadap fenomena.

- Konstruktivisme sosial. Pengetahuan merupakan produk interaksi simbolik dalam kelompok-kelompok sosial.

- Pendekatan Holistik - gestal. Keseluruhan yang terdiri dari bagian-bagian.

- Tacit. Pengetahuan bawah sadar.

- Eksplisit. Pengetahuan dapat diartikulasikan dengan eksplisit.

\section{Ontologi}

Berbicara tentang bagaimana pengetahuan itu dimaknai:

- Berbicara tentang Known, yaitu makna pengetahuan itu sendiri.

- Berbicara tentang Knower, yaitu siapa berbicara tentang apa.

- Penilaian tentang siapa yang mengetahui.

- Penilaian tentang sifat dan karakter makhluk hidup.

- Berpusat pada aspek interaksi.

\section{Aksiologi}

- Berbicara tentang nilai guna laksana suatu ilmu. Apa manfaat ilmu tersebut bagi kehidupan manusia. 
- Dalam aspek apa teori tersebut dapat diimplementasikan.

\section{PARADIGMA ILMU INFORMASI}

Richard Apostle dan Boris Raymond (1997) mengatakan bahwa pandangan tentang paradigma Ilmu Informasi itu masih banyak, sehingga menimbulkan kebingungan terutama kaitannya dengan perencanaan yang akan dilakukan para pendidik dalam penyusunan kurikulum. Walaupun sadar atau pun tidak sadar bahwa asumsi tersebut akan menimbulkan kekurangajegan pemaknaan terhadap kepustakawanan (Librarianship) karena tidak ada satu kesepakatan antara konsep Ilmu Informasi dan Kepustakawanan (Librarianship). Akan tetapi keduanya sama-sama mengkaji tentang informasi walaupun di dalam tradisi yang berbeda. Budaya ilmu sosial dibedakan dengan paradigma sain dimana sosial sain dapat didefinisikan sebagai logika positivisme, apabilla subjek matter sosial sain yang dihasilkan menyerupai sain atau orientasi keilmuanya dapat menyerupai sain sehingga dapat menyerupai paradigma positivisme. Berbagai argumen tentang paradigma sosial sain menyatakan dapat masuk ke ranah positivisme atau post positivisme, seperti diungkapkan oleh Wilson. Sebagai contoh pada kajian perilaku pencarian informasi. Para pengguna informasi apabila mengkaji informasi topik yang berkaitan dengan perasaan, emosi, maksud, sikap termasuk didalamnya mengkaji tentang pemaknaan terhadap sesuatu objek, maka paradigmanya adalah post-positivisme. Apabila kajiannya berkenaan dengan perilaku pencarian informasi seperti frekuensi kunjungan, banyaknya sumber informasi yang digunakan, keterkaitan antara perilaku dengan kebiasaan memilih dan menentukan sumber informasi yang dibutuhkan, dengan tingkat kecerdasan, status ekonomi, sosial dan lain-lain, masuk paradigma positivistik.

Kajian tentang informasi dan perpustakaan dapat dilihat dari dua sisi pendekatan (paradigma). Paradigma positivisme atau postpositivime. Herbet Menzel mengkategorikan kajian informasi menjadi:

- Behaviour studies dengan pendekatan positivistik.

- Use studies, bisa dengan pendekatan positivistik dan post-positivistik.
- Pattern of flow media studies dengan pendekatan post-positivistik.

Dilihat dari kedua paradigma teori, maka Ilmu Informasi dan Perpustakaan dapat didudukan pada bidang sain atau sosial. Kedudukan dalam disiplin Ilmu Komunikasi bahwa informasi disebarkan melalui kegiatan ilmiah seperti melalui buku teks, jurnal, makalah seminar yang dikenal dengan istilah komunikasi ilmiah (scientific communication).

\subsection{Komunikasi Ilmiah}

Suatu kegiatan para sarjana atau saintis dan tenaga profesional lain berkomunikasi dengan para sarjana dan saintis lainya. Pola komunikasi ilmiah yang dimaksud adalah bahwa para sarjana, saintis, dan para profesional itu menyampaikan pesan ilmiah berupa makalah, skripsi, thesis, dan disertasi serta jurnal dan buku kepada para profesional lainnya dalam kegiatan seminar, lokakarya, temu ilmiah pendidikan dan pertemuan yang sifatnya non formal. Kemudian mereka saling mensitir di antara para ilmuwan tersebut untuk kepentingan penelitian dan kegiatan ilmiah lainnya. Pola komunikasi ilmiah merupakan interaksi setara di antara para ilmuwan, sarjana dan para profesional.

Bagaimana tukar-menukar informasi ilmiah di kalangan para ilmuwan baik dalam bidang ilmu yamg sama atau berlainan bidang ilmu. Bentuk tukar menukar tersebut biasanya adalah saling "sitir" atau saling tukar karya atau kolaborasi karya yang dikenal dengan karya bersama.

\section{Sample of Reference (Referensi pilihan)}

Merupakan artikel (ilmiah) yang dianggap mutakhir. Tidak selamanya artikel terbaru dalam sebuah jurnal, namun sebagian dari pengguna menganggap artikel itu baru diketahui, padahal kalau dilihat umumnya mungkin diatas 5 tahun bahkan lebih dari 10 tahun. Dalam kajian bibliometrik bahwa sample reference, merupakan contoh-contoh artikel yang disitir. Artikel dimaksud adalah artikel yang ada pada jurnal ilmiah yang ditulis oleh para ilmuwan dari hasil kajian dan penelitian-penelitian yang ia lakukan baik merupakan pengkajian tentang teori atau penemuan-penemuan teori-teori baru. Kemudian hasil kajian itu disitir, dikutip ilmuwan lain. Setiap ilmuan dalam melakukan kajiannya itu menyitir karya-karya ilmuwan lain yang telah dilakukan lebih dahulu. Proses sitir-menyitir 
diantara para ilmuan disebut Scientific Communication (Komunikasi Ilmiah).

\subsection{Model Komunikasi Ilmiah}

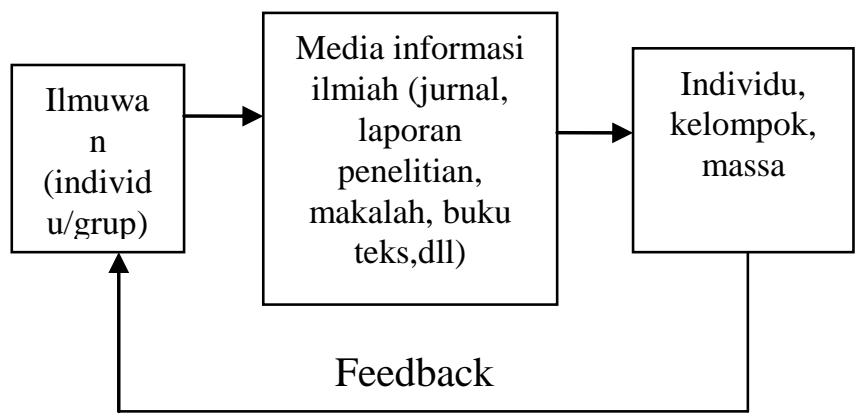

Dalam rangka menghitung jumlah karya artikel sitiran dan kutipan dihitung dengan berbagai model atau formula dari komunikasi ilmiah, diantaranya:

-Booth's Law

-Bradford's Law

-Brookes's Law

-Lotka's Law

-Price's Law

-Zipf's Law

-Dan lain-lain.

Berikut adalah contoh pembahasan dari beberapa model, sbb:

\section{Formula Bradford}

Salah satu model dari hokum Bradford adalah bibliograph yaitu jumlah artikel dalam jurnal, kemudian rangking logaritma dari jumlah sumber (jumlah) pada daerah horizontal. Dari hasil analisis akan digambarkan dalam formula tersebut, yaitu J Kurve dan S Kurve. Dimana J Kurve menggambarkan tentang bentuk $\mathrm{J}$ dan $\mathrm{S}$ Kurve menggambarkan tentang bentuk $\mathrm{S}$. semuanya menggambarkan tentang ranking sitiran artikel jurnal. Proses tersebut menggambarkan tentang komunikasi ilmiah, yaitu pola komunikasi ilmiah yaitu pola jejaring para ilmuwan melalui kegiatan saling menyitir.

\section{Formula Lotka (Lotka's Law)}

Salah satu bentuk hukum dalam bibliometrik untuk menghitung periode waktu (usia) dari publikasi bidang ilmu dari seorang pengarang dikaitkan dengan banyaknya publikasi pada bidang tersebut atau menghitung hubungan terbaik/perbandingan antara jumlah dokumen yang dihasilkan dengan jumlah pengarang yang menghasilkan dokumen pada bidang studi tersebut.

\section{Formula Pareto (Pareto's Law)}

Hukum ini menganalisis jumlah komunitas yang menjadi anggota sebuah lembaga informasi dengan rumus:

$$
\mathrm{r}=\frac{\mathrm{A}}{\mathrm{Ya}}
$$

Dimana:

$\mathrm{R}=$ jumlah individu yang membayar iuran anggota dalam bentuk Rp. Y

$\mathrm{A}=$ Parameter komunitas yang dianalisis

\section{Formula Price (Price's Law)}

Dikenal juga dengan Price's Index yaitu mengukur jumlah resensi yang disitir dari sebuah dokumen atau jurnal dalam berbagai disiplin ilmu.

\section{Formula Zipf (Zipf's Law)}

Menghitung frekuensi penggunaan kata yang ada pada teks yang dianalisi, dengan rumus: $\mathrm{r}^{*} \mathrm{t}=\mathrm{C}$

Dimana:

$\mathrm{r}=$ rangking dari kata yang digunakan pada $\mathrm{f}$

$\mathrm{c}=$ parameter teks yang dianalisis

\subsection{Paradigma Kualitatif dan Kuantitatif dengan Pendekatan Expectations Theory}

Penti Vokari:

Bidang Ilmu Informasi dan Perpustakaan dalam tradisi dokumentasi dekade tahun 1970-an:

- Topik riset mengarah pada diskusi tentang keterkaitan antara Ilmu Perpustakaan, Ilmu Informasi dan Dokumentasi

- Definisinya menjelaskan tentang konsep dasar Knowledge Information dan kebutuhan informasi (Information Need) .

- Opini yang dibangun yaitu: keterkaitan antara perkembangan disiplin sosial dan psikologi kognitif, di mana dua dimensi tersebut yaitu:

a. Dimensi tingkatan organisasi internal dan kelembagaan

b. Dimensi interpretasi struktural fungsional, dimana struktur mempunyai bagian dan sub bagian, yang semuanya mempunyai tugas pokok dan fungsi masing-masing. 
Hal ini tercermin dalam penyusunan kurikulum pendidikan tersebut yang mengarah pada kurikulum berbasis kompetensi individual, kognitif, afektif dan psikomotorik.

- Program studi Ilmu Informasi dan Perpustakaan dimulai pada tahun 1950-an. Merupakan integrasi sebagai salah satu departemen (jurusan) di sebuah universitas pada level graduate (sarjana) kemudian sampai pada level doctoral (S3).

- Hal ini merefleksikan bahwa Ilmu Informasi dan Perpustakaan merupakan disiplin keilmuan yang tidak hanya menghasilkan lulusan dengan latar belakang pengetahuan profesi akan tetapi lebih ke pengembangan kognisi (Cognitive institue socialization discipline).

- Cognitive institute socialization ini menunjukan perlu adanya kejelasan dari kekuatan dasar teoritis (Grand Theory) yang akan menjelaskan tentang arah objek atau bidang penelitian atau kajian utama Ilmu Informasi dan Kepustakaan. Social institute socialization mengarahkan pada Cognitive institute socialization pada dekade tahun 1970-an banyak hal penting yang mengarahka pada dua kegiatan kajian yaitu fenomena tradisional yang memandang informasi dan perpustakaan sebagai institusi pelayanaan. Sedangkan yang kedua mengarahkan pada fenomena akses dan kebutuhan informasi, serta pencariannya.

- Kerangka teoritis akan berpengaruh pada penilaian teori. Fenomena sentral dari Ilmu Informasi dan Perpustakaan menimbulkan tiga perbedaan perspektif, yang mengacu pada perkembangan teori dan penetapan argumen serta bagi penemuan sesuatu yang baru dari beberapa keberhasilan analisis teoritis. Keberhashilan teoritis dan empirik akan berkontribusi kepada pengembangan bidang keilmuan informasi dan kepustakaan. Permasalahan yang diminati untuk dikaji akan mengembangkan diri karena ilmu bermula dari kajian itu sendiri.

Pengembangan keilmuan di atas tentunya akan mengarah kepada penempatan Program Studi Ilmu Informasi dan Perpustakaan itu sendiri. Bagi Ilmu Informasi yang berbasis pada disiplin matematika yang dikembangkan dari Mathematical Theory of Communication, dengan binnary digit (0-1), tentunya akan menginduk pada Matematika dan Ilmu Pengetahuan Alam. Penelitiannya pun menganut pendekatan objektivis. Selanjutnya dari tradisi pengguna informasi, dapat ditinjau dari dua sisi, yakni sisi peta sosial dan psikologi (perilaku), sehingga pada waktu penempatan Program Studi Ilmu Informasi dan Perpustakaan ditempatkan pada bidang disiplin ilmu sosial atau komunikasi seperti di Fakultas Ilmu Komunikasi Universitas Padjadjaran.

Di beberapa perguruan tinggi di Indonesia, Ilmu Informasi dan Perpustakaan ditempatkan di Fakultas Ilmu Sosial dan Ilmu Politik dan pada Ilmu Budaya, dengan alasan bahwa informasi adalah pengetahuan yang merupakan bagian dari budaya yang dengan kata lain masuk ke dalam disiplin Ilmu Sosiologi dan Antropologi, sehingga paradigmanya pun menggunakan sosioantropologi. Kajian yang dilakukan pada bidang ini bisa menggunakan paradigma post-positivistik, sedangkan pada sosial-antropologi atau pada aspek perilaku (sosial-psikologi). Paradigmanya objektivis atau positivistik, sehingga penempatannya pada bidang ilmu sosial.

Berikutnya, karena fokus kajiannya pada teknologi informasi yang melibatkan pula perangkat keras (hardware) dan perangkat lunak (software), maka Program Studi Ilmu Informasi dan Perpustakaan ditempatkan pada ilmu teknologi seperti di Filipina dan beberapa negara Eropa dan sebagian di negara Amerika.

Ada juga yang berpandangan bahwa Ilmu Informasi dan Perpustakaan dipandang sebagai ilmu interdisiplin maka ilmu tersebut ditempatkan pada Program Studi Interdisiplin, bergabung dengan beberapa bidang studi lainnya yang 
sifatnya umum, seperti Ilmu Komputer, Ilmu Linguistik dan Kebijakan Publik.

\section{KOMUNIKASI, INFORMASI PERPUSTAKAAN}

\subsection{Unsur Komunikasi}

Beberapa unsur dalam komunikasi antaranya adalah :

a. Bahasa/Simbol

b. Pengirim - Penerima

Pesan - Saluran

c. Gangguan

$$
\begin{array}{r}
\text { Saluran - Media - Formal } \\
- \text { Informal }
\end{array}
$$

d. Bahasa, merupakan alat utama dalam konteks komunikasi:

- Cerminan individu dan kebudayaan masyarakat.

- Pertumbuhan dan pewarisan kebudayan, kelangsungan hidup masyarakat dan fungsi perpustakaan.

d. Simbol:

- Terbuka

- Terlihat

- Teraba

- tercium

- Abstraksu ke dalam objek yang terbatas

e. Verbal - Kata-kata

Non verbal - gesture

\subsection{Proses komunikasi, bahasa, simbol, pesan}

Sumber $\rightarrow$ (saluran) $\rightarrow$ Tujuan (penerima pesan) Gangguan

Hambatan

Penerimaan Pesan

Saluran :

- Kredibilitas saluran

- Umpan balik saluran

- Kesediaan saluran

- Kemampuan saluran menyampaikan

- Kemampuan melipatgandakan saluran

- Kemampuan saling melengkapi

\subsection{Definisi komunikasi}

Harthley (1961) dan Little john mengatakan bahwa proses komunikasi semua fungsi sosial dari mahluk hidup. Pada manusia proses komunikasi sangat penting bagi perkembangan setiap orang, bagi pembentukan dan kelangsungan wujud kelompok-kelompok dan bagi setiap hubungan diantara kelompok-kelompok.

Sementara Garthner (1958) berpendapat bahwa komunikais sebagai suatu interaksi sosial melalui pesan-pesan yang dapat diberi sandi (Kode secara formal, simbolis atau penggambaran peristiwa tentang bebebrapa aspek budaya yang sama-sama dimiliki.

Komunikasi adalah penyampaian informasi ide perorangan dan lain-lain melalui symbolsimbol, kata-kata, gambar, angka-angka tulisan dan lain-lain. Peristiwa itu adalah kegiatan atau proses yang disebut komunikasi

Miller (1966) menyoroti proses komunikasi di mana sumber (source) menyampaikan pesan kepada penerima dengan niat sadar untuk mempengaruhi perilaku penerimanya. Bagi setiap orang komunikasi mewujudkan 3 fungsi:

1. Komunikasi membentuk dunia sekeliling individu.

2. Komunikasi kedudukan individu sendiri menetapkan dalam hubungannya dengan orang lain.

3. Komunikasi membantu individu dalam menyesuaikan diri dengan sekeliling. (Hartley)

Pokok bahasan utama kajian komunikasi adalah prodoksi organisasi, komposisi, struktur, distribusi, sejarah perkembangan sejarah, dan fungsi system pesan dalam masyarakat. (garbner, 1958). Selanjutnya Smith (1466) mengemukakan tiga pendekatan komunikasi:

1. Pendekatan matematika

2. Pendekatan psikologi sosial

3. Pendekatan antropologi

Linguistic - communication and culture.

Penelitian: sintaksis semiotik, dan pragmatik.

\section{Pengertian Teori}

Meta teori - analisis, investigasi, deskripsi dari teori (Webster International Dictionary, 1969) Teori

A.Batang tubuh dari generalisasi dan prinsipprinsip yang dikembangkan pada asosiasi 
dengan praktis pada pembentukan lapangan aktivitas dari disiplin intelektual.

B. Sistem dari berbasis asumsi, prinsip-prinsip dan aturan untuk menganalisis, memprediksi atau menyelesaikan secara alami dari suatu kesatuan fenomena.

C. Model adalah suatu tentative dari ide yang digunakan, alat coba (American Heritage) 1969.

\section{Salah Satu Teori Komunikasi}

\section{Teori Interaksi Simbolik}

Teori Interaksi simbolik dari George Herbert Mead, bahwa studi tentang manusia tidak dapat dilaksanakan dengan metode yang sama.

Tiga tema besar:

- Pentingnya makna bagi perilaku manusia.

- Pentingnya konsep mengenai diri

- Hubungan individu denga masyarakat

$\checkmark$ Individu membentuk makna lewat komunikasi

$\checkmark$ Manusia bertindak terhadap manusia lainya berdasarkan makna yang diberikan orang lain pada mereka

$\checkmark$ Makna diciptakan dalam interaksi antar manusia

$\checkmark$ Makna dimodifikasi melalui proses interpretasi

\section{Teori Sosiokultural}

Interaksi simbolik $\longrightarrow$ sosiologi konstruksivisme

- Sosiolinguistik

- Flosofi bahasa

- Etnografi

- Etnometodologi

Interaksi simbolik kajian

Sosiologi - Kenneth Burke

Interaksi sosial - George Herbert Mead

Konstruktivisme - Peter Berger

\section{Social Construction Reality}

Interaksi Sosial

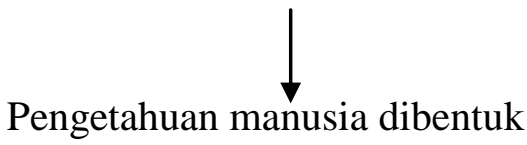

Sosiolinguistik - kajian bahasa dan budaya yang menyatukan bahasa sebagai jati diri manusia sebagai makhluk sosial. Kajiannya juga dengan filosofi bahasa. Makna bahasa tergantung pada penggunaan nyatanya.

- Bahasa - permainan bahasa setiap manusia yang menggunakan bahasa harus mengikuti aturan mainanya,

- Pendekatan sosiokultural yang lain adalah:

- etnografi - observasi terhadap bagamana kelomppok sosial membangun makna melaui perilaku linguistik dan non linguistik mereka. Etnografi - melihat bentuk-bentuk komunikasi yang digunakan dalam kelompok sosial tertentu. Kata-kata yang mereka gunakan dan apa maknanya bagi mereka.

- etnometodologi - observasi ynag cermat akan perilaku-perilaku kecil dalam situasi nyata (Harold Yanfukel). Melihat bagaimana perilaku dalam interaksi sosial pada waktu tertentu - dalam komunikasi melekat bagaimana percakapan, termasuk partisipan mengelola akan percakapan dengan bahasa dan perilaku non verbal

\section{Tradisi Kritik}

Ada tiga kriteria tradisi kritis yaitu:

1.Memahami sistem yang sudah dianggap benar, struktur kekuatan dan keyakinan atau idiologi.

2. Pada umumnya teori kritik tertarik pada membuka kondisi-kondisi sosial yang menindas dan mengklaim kekuatan untuk mempromosikan emansipasi atau masyarakat yang lebih bebas dan lebih berkecukupan. Memahami pandangan ideologi.

3. Menciptakan kesadaran untuk menggabungkan teori dan tindakan.

Seringkali dalam kajian komunikasi tertarik pada bagaimana pesan memperkuat dan penekanan dalam masyarakat.

- Fokus pada wacana dan teks yang mempromosikan ideologi-ideologi tertentu, membentuk dan mempertahankan kekuatan, 
menumbuhkan minat-minat kelompok atau kelas tertentu.

- Analisis wacana kritis memperlihatkan fiturfituar aktual dalam teks yang memunculkan rangkaian penekanan tersebut.

- Teori Kritis - Marxisme

- Frankfrut School of Critical thory

- Post Modernisme

- Kajian budaya

-Post -Strukturalisme

-Post - Kolonialisme

-Feminisme

- Post Feminisme

\subsection{Komunikasi Vs Informasi}

Para sarjana mengalami kebingungan memaknai komunikasi kaitannya dengan informasi. Pertama, proses komunikasi sebagai objek dari kajian dan komunikasi merupakan bidang ilmu yang mengkaji proses. Komunikasi (bidang) mengkaji (proses) komunikasi berbagai teks tentang komunikasi mulai merancang/ menggunakan puluhan ribu data. Komunikasi diidentikan sama dengan informasi. Walaupun para ahli belum ada kesepakatan yang jelas.

Namun mereka mendiskusikan tentang informasi sebagai "knowledge message" dan komunikasi sebagai proses. Hubungan antara pesan dan proses, yaitu informasi sebagai sain (information science), komunikasi sebagai bidang kajian (field) terpenuhi. Para sarjana komunikasi terutama para filsuf lama memandang komunikasi sebagai retorika (Public Speaking). Kajian Aristotele kajian tentang persuasi dan efek.

Penelitian bidang komunikasi menyertakan kajian empiris, pengumpulan data, uji hipotesis, dan penerapan semua cara kajian ilmiah modern. Ilmu Komunikasi merupakan disiplin ilmu tersendiri yang mengkonsentrasikan diri pada komunikasi manusia (Human Communication). Namun kedua bidang ilmu tersebut dapat melakukan kajian dalam fokus yang sama, misalnya kajian tentang knowledge gaps (hambatan pengetahuan), invisible colledge, difusi inovasi, interaksi antar manusia (Human
Interaction) dengan menggunakan teknologi komunikasi, perilaku pencarian informasi, teori informasi, sistem informasi dan masyarakat informasi. Kaitannya dengan perpustakaan adalah informasi sebagai pengetahuan atau merupakan suatu kemampuan pengetahuan yang terorganisir. Penekanan kajian pada komparatif sistematik subjek area pengetauan. Artinya paradigma penelitian memperlihatkan kajian empirik kuantitatif - dengan pengumpulan data, analisis data kuantitatif (statistik) dan hasilnya dalam bentuk dalil-dalil dan teori-teori kemudian paradigma kualitatif penekananya pada eksplorasi data, memaknai, mengkonstruksikannya dan kemudian menyimpulkan menjadi kerangka pendukung terhadap teori-teori yang dihasilkan melalui kajian kuantitatif.

Perpustakaan merupakan lembaga yang mendokumentasikan hasil-hasil kajian sebagai sumber pengetahuan yang akan diakses dan digunakan oleh para pemustaka karya (pemakai). Kesiapan pendokumentasian pada dasarnya adalah scientific communication (komunikasi ilmiah) dengan kegiatan mencari melalui analisis kebutuhan, penyampaian, pengolahan, pengorganisasian, penyebaran dan menyalurkan informasi (knowledge) kepada penggunanya.

\section{UNIVERSITAS BERBASIS PENDIDIKAN INFORMASI DAN PERPUSTAKAAN}

Universitas yang mempunyai program kajian Ilmu Informasi (Information Science) menyatakan bahwa akar dari kajian Ilmu Informasi dan Perpustakaan adalah sama, yaitu sama-sama mengkaji tentang informasi. Isu pernyataan kajian informasi dan perpustakaan sudah mulai diwacanakan pada tahun 1960-an, mengkaji tentang program pengajaran.

Riwayat pendidikan Ilmu Perpustakaan mulai dari tahun:

1918-1945 Sekolah perpustakan kecil untuk mendidik pustakawan.

1946-1975 Sekolah perpustakaan besar untuk mendidik pustakawan dan tenaga akademisi tenaga peneliti, sampai ke tingkat doktoral. 
1976-1994 Muncul program pendidikan Manajemen Informasi, termasuk di dalamnya pelayanan perpustakaan dan penelusuran informasi

1995 Pada tahun ini mencatat program manajemen informasi mencakup layanan perpustakaan, analisis dan teknik pengelolaan perpustakaan berbasis komputer.

Bermula dari kondisi seperti ini maka perubahan terjadi dari school of library science kepada school of library science dan dari school of information science ke information management. Kemudian menjadi information studies. Pada Program Studi Ilmu Informasi munculnya paradigma tradisi dokumentasi dan tradisi komputerisasi.

\section{DAFTAR PUSTAKA}

Shannon, C \& Weaver,W. 1949. The Mathematical Theory of Communication. Anbana: University of Illionis Press.

Taylor, Arlene G. \& Joudrey, Daniel N. 2009. Organization of Information. Westport: Greenwood Publishing.

Yahya, Harun. 2005. Rahasia DNA: teori Informasi dan Akhir dari Internalisme. Harun Yahya International.

Buckland, Michael. 1998. The Hanscape of Information Science: The American Society for Information Science. Barkeley: University of California.

Fenner, Audrey. 2002. "Placing Value on Information". Library Philosophy and Practice Vol. 4 No.2 (Spring 2002).

Apostle, R \& Raymond, B. 1997. Library and the Information Paradigm. Lanham, MD: Scarecrow Press. 